and unly ten elements were used in the sub-Mediterranean cable. The triangulation of Algeria is an accomplished fact, and the calculations will be finished two or three months hence. When the operations shall have been completed it will be possible to know the exact length of an arc of meridian passing through the Paris Observatory, and extending from Shetland to Iaghouat. The amplitude will be exactly $30^{\circ}$. An arc of parallel will be measured, also extending from Nemours on the Marocco frontier to Bona, in the vicinity of Tunis. The mean latitude will be $36^{\circ}$ and amplitude $10^{\circ}$.

THE following courses of instruction for science teachers will probably be organised this summer at South Kensington :- . Chemistry (Elementary), from July 4 to July 26 , by Mr. W. Valentin, F.C.S. ; 2. Sound, from June $x 9$ to July 11 ; 3. Light, from July 12 to August 3, both by Prof. Guthrie, F.R.S.; 4 . Steam, from July 4 to July 26, by Prof. Goodeve, M.A., and Prof. Shelley; 5. Biology, from June 13 to July 5 , by Prof. Huxley, Sec. R.S. Details may be obtained by application to the Science and Art Department.

THE avard of the Public Schools' I'rize Medals of the Geographical Society for the present year has been as follows :Physical Geography-Gold medal, Walter New, Dulwich College ; Bronze medal, Arthur Smyth Flower, Winchester College. Political Geography-Gold medal, William John Newton, Liverpool College; Eronze medal, John Wilkie, Liverpool College.

ARTrFICrax flowers called barometors are being now exhibited in a number of Parisian opticians' shops. They are coloured with a material composed of chloride of cobait. When exposed to sun and dry air the leaves become deep blue; when the air is saturated with moisture they become pinky. All the intermediate shades are easily observed.

A REPORT from Dr. v. Bary on his recent excursion into the Tuareg region of the Western Sahara was read at the last meeting of the Berlin Geographical Society. His researches yield but few grounds in support of the theory that the Sahara was formerly the bed of a sea. He is inclined more to the belief that North Africa has long been free from a covering of water, as no traces of Tertiary formations were found, and the sand-downs cannot be regarded as proofs of the former existence of a sea. The traveller found the valley of Mihero not only remarkable for the number of crocodiles existing in its pools, but also on account of the rich growth of trees in striking contrast to the surrounding deserts. A mass of luxuriant climbing plants prevents the passage of beasts of burden.

FINNISI papers report that vast masses of smoke are issuing from a mountain adjoining the river Tana, and that the snow in the vicinity has been melted away. The region has hitherto been free from evidences of volcanic activity. The theory has often been advanced that the gradual elevation of the shores of the Gulf of Bothnia is due to volcanic forces, and it is possible that these are finally seeking a vent.

The royal tigress in the Berlin Zoological Gardens, lately brought forth a litter of two, which she utterly refused to take care of. They were accordingly placed amidst the family of a Newfoundland dog, who welcomed the new-comers warmly and bestows upon them all necessary maternal attentions.

AN extensive movement of subsidence has taken place at Marano Marchesato, in the territory of Cosenza (Calabria). Vast chasms have opened, a great number of houses have been destroyed, and many others threaten ruin. The movement extends to the north, passing the hills of S. Fili e Bucita as well as to the river that 'divides Marano from Rende, the waters of which are partly escaping through large fissures in its bed. At the observatory of Cosenza there have been noticed for some time a barometrical depression of $10 \mathrm{~mm}$., an extraordinarily low state of temperature with variable winds, fresh snow on the mountains, and a very abundant rainfall. The magnetic instruments, too, show an extraordinary agitation.

The town of Iquique, in Peru, was visited by a destructive earthquake on May Io. The damage done is not so great as was at first anticipated, and it is stated that no lives have been lost. Early on the following day, between 2 and 3 A.M., a shock of earthquake is reported to have occurred at Comrie and the surrounding district of Perthshire; the shock, as usual, came apparently from south-west, proceeding to northeast, and was accompanied with a noise resembling that of distant thunder or the discharge of cannon. On May 2 several shocks of an earthquake were experienced in the neighbourhood of Löfta, in Sweden, causing some degree of damage.

In the April session of the Berlin Anthropological Sociely, Baron v. Schleinitz, commander of the late German exploring expedition, gave an extended account of his anthropological studies among the inhabitants of New Guinea and the islands of the Melanesian Archipelago, which possess an interesting character on account of the isolated character of the region. The natives belong almost exclusively to the pure Papuan race. Three sharply-disinguished types were noticed. Thefirst, prevalent in the northern part of New Guinea, is characterised by a thin, ill-shaped, hairy body, smooth face, thick lips, woolly hair, prognathous features, thin calves, \&c. A second, occupy. ing the islands of New Hanover and New Ircland, is slightly modified. The colour is a light brown, scarcely darker than that of South Europeans; the body is better proportioned and more fully rounded; clothing is not woris by the men and rarely by the women. A comparatively strict observance of morality, the rights of property, and family relations was, however, observed. A third race, found on the westem coast of New Guinea, evidently possesses a slight mixture of Malaysian blood. They are russet brown and dolichocephalous, with intelligent and handsome features, and well proportioned form. Many of the tribes inhabit villages built on piles and well secured against attack. Polygamy is prevalent in certain regions, and a legalised system of marriage appears to be general.

We have received from Prof. Henrici the sum of $x l$. ros. towards the Gauss Monument Fund.

THE additions to the Zoological Society's Gardens during the past week include a Hoolock Gibbon (Hylobates hoolock) from Assam, presented by Mr. John Scrymgeour; two Mauge's Dasyures (Dasyzirus maugai ) from Australia, presented by Capt. J. C. Harris; an Antarctic Skua (Stercorarius antarcticus) from the Antarctic Seas, a Ceylon Hawk Eagle (Spizaëus ceylonensis) from Ceylon, presented by Capt. W. Vincent Legge; two White eared Conures (Conurus leucotis) from South America, presented by the Lady Greville; three Touracous (Corythair persa) from West Africa, presented by Mr. J. G. Tayler and Capt. R. H. Crewe; a Saddle-billed Stork (Xenorhynchus senegalensis), a Black Sternothere (Sternothorus niger) from West Africa, five Kappler's Armadillos (Tatusia kappleri) from South America, purchased; a Wild Boar (Sus scrofa), born in the Gardens.

\section{UNIVERSITY INTELLIGENCE}

OXForD. - The Master and Fellows of Balliol College give notice that they are willing to receive as members of the College without further examination, selected candidates for the Indian Civil Service, not exceeding in number ten, and to assist in their education. Any candidate who wishes to avail himself of this proposal is requested to communicate with the Master of Balliol.

CAMBRIDGE. - The Adams Prize awarded biennially for the best essay on some subjects of Pure Mathematics, Astronomy, 
or other branch of Natural Philosophy, the competition being open to all persons who have at any time been admitterl to a clegree in the University of Cambridge, has been adjudged to Iidward John Routh, M.A., F.R.S., St. Peter's College. 'The subject of the essay is "The Criterion of Dynamical Stability." The value of the prize is about $25 \%$.

$\Lambda$ Warden of Cavendish College in the place of the Rev. $T$. I. I awrence, resigned, will le clected on Tuesday, June 5. The College is intended for students somewhat younger than ordinary undercraduates, and the teaching and discipline correspond with those of the higher forms in a public school. The salary is $500 \%$, , or a capitation fee of $5 \mathrm{l}$. when the number of students excecils roo. Candidates are requested to communicate with the Rev. Prebendary Jirereton, Little Massingham, Rougham, Norfolk.

Glascow.-The Town Council has given a subscription of 5,000 ? . to the funds of the University of that cily.

BRISTOL.-It will be seen from our advertising columns that a Trincipal is wanted for University College. For so young an institution the salary offered is very fair, and we hope that a thoroughly good man will be obtained for the post, one who, if not a man of science himself, at least regards it as of equal importance with literature.

\section{SOCIETIES AND ACADEMIES \\ LONDON}

Royal Society, April I2.--" On certain Molecular Changes which occur in Iron and Steel during the separate acts of Heating and Cooling," by Prof. Norris, M.D., Queen's College, Birmingham.

An exhaustive study of the various conditions has led to the elucidation of the nature of hardening, softening, tempering, arnealing, Sc., and has further shown that numerical values may be assigned to these states.

The research has further established the existence in steel and in iron containing free carbon of a contraction or shortening which is excited by heat, and which proceeds simultaneously with the dynamical expansion, and masks its true amount. This is divisible into high and low lemperature contraction.

The presence of a cooling expansion or crystallisation, which comes in during the dynamical contraction, and masks its true amount.

Thicse effects, due to crystallisation and decrystallisation, are the causes of the so-called kicks, or temporary contractions and expansions which occur during the heating and cooling of the steel.

That the low-temperature contraction and cooling expansion are due to decrystallisation and crystallisation which occur during the acts of heating and cooling, while the kicks themselves are simply the thermal effects associated with these changes, and are proportionate to their extent.

That protracted annealing, that is, extremely slow cooling, brings about molecular separation of the carbon and iron; and steel. in such a state contracts greatly when high temperatures are reached, producirrs the contraction returns seen at the end of the heating, and which are due to the condensation produced by the recombination of the carbon and iron. Steels in this state are less susceptible to cooling expansion (crystallisation), and therefore to low temperature contraction on subsequent heating.

April 26.- "Researches on Emeralds and Beryls.-Part II. On some of the Processes Employed in the Analysis of Emeralds and Beryls," by Greville Williams, F.R.S.

"Or the Nature and Origin of the Beds of Chert in the Upper Carboniferous Limestones of Ireland," by Prof. Edward IIull, M.A., F.R.S., Director of the Geological Survey of Ireland. With "Chemical Notes," by E. T. Hardman, F.C.S., of the Geological Survey of Ireland.

From a review of the whole circumstances, it appeared that the origin of the chert-beds was to be attributed to the replacement of the original limestone or calcareous " ooze," due to organic agency by silica, and that the rock is truly a pseudomorph, a view held by several observers.

The manner in which this replacement had been brought about was then touched upon. It. was shown that there was reason for believing that at the close of the period during which the carboniferous limestone was formed over the area of Central Ireland, the sea-bed was elevated so as to be covered by the waters of a shallow sea exposed to the sun's rays, and of a warmer temperature than when at a greater depth. The waters appear to have been charged with a more than usual supply of silica in solution, derived (as $\mathrm{Mr}$. Hardman suggests) from the surrounding lands, formed, for the most part, of highly silicens materials. As silica is less soluble than carbonate of lime, chemical replacement would naturally take place, the carbonate of lime being dissolved out and its place taken by the silica. The warm condition of the sen-water, its exposure to sunlight, the porous character of the corall ne, crinoidal and other forms, and the soft and "oozy" condition of the foraminiferal mud would give easy access to the sea-wa!ers, and the process of silicification would take place analogous to that described by Dr. Martin Duncan, F.R.S., as having occurred in the West Indies.

Linnean Society, April I9.-G. Bentham, F.R.S., viceprecident, in the chair.-M. Cassimir De Candolle read an important paper on the geographical distribution of the Meliaceæ. His general conclusions with regard to the Melia family may thus be summarised: $(a)$ The number and the mutual affinities of the various genera of Meliacex decrease from the Asiatic region towards Africa and America on one side and towards East'Poly. nesia on the other; (b) Between the Meliacere of America and Africa there exists analogy, whilst Polynesian species belong to Indian type; (c) New Caledonia contains within itself a remarkable number of distinct species, the type of which, however, is Indian ; $(d)$ in Australia three Indian genera are found, along with three genera exclusively belonging to Australia; $(e)$ No species of Meliacere have hitherto been collected in the most"eastern islands of Polynesia; if subsequent observations reveal such it will be interesting to know whether they pertain to Indian or American type.--Another contribution on the geographical distribution of the Indian fresh-water fishes (Part II. The Siluridæ), read by Dr. Francis Day, curiously enough in some ways points to a similar conclusion to that derived from the plants above-mentioned. Dr. Day showed that of the twenty-six genera of Silu. roida represented in the Indian Empire, ten are found in the Malay Archipslago, two more reach Cochin China or China, whilst Clarias only is common to India and Africa, and moreover it likewise is found in the Malay Archipelago. He infers that the said freshwater fish of India are more closely related to a Malayan than to an African fish fauna.-Mr. R. Irwin Lynch, of Kew Gardens, brought before the notice of the Society some observations on the disarticulation of the branches of Castilloa elastica, the caoutchouc tree of Central America. He has noticed that the lateral branches are detached from the ascending stem of the plant in a regular manner from below upwards in the same way as leaves, and this happens always at the point of insertion. In certain Euphorbiaceous genera which have leaf-liketbranches, these fall as does a leaf, and they bear in their axils a bud from which alone the permanent branches are produced. They are themselves subtended by a leaf reduced to a scale.-Capt. Chimmo followed by two communications, one concerning the mode of obtaining and the structure of the so-called Euplectella of the Philippines, the other a description of a supposed new Rhizopod.

Anthropological Institute, May 8.-John Evans, F.R.S., president, in the chair.--Special thanks were voted for the present to the Library of a complete set of the volumes relating to the voyage of the Novara, published and presented by the Austrian Government. - On an exhibition, by Mr. R. Biddulph Martin, of objects from a large refuse heap in the neighbourhood of Smyrna, Mr. Hyde Clarke, Col. Lane Fox, and the president offered remarks.-Mr. A. L. Lewis communicated a description of the remains of a stone circle at Colderham, Kent, illustrating his remarks by a well-prepared plan.-Dr. John Rae read a paper on the skulls of the Esquimaux, attributing the fact that two distinct types of skull exist among these peoples to an admixture of blood. An interesting discussion followed, in which Dr. Beddoe, Col. Lane Fox, and others took part.-Dr. Beddoe, F.R.S., communicated a paper on the Aborigines of Queensland, whom he described; on the authority of Mr. Christi. son, who had had many years' knowledge of them, and employed them very largely in sheep-farming, to be, in many respects, not so black as they have been painted.

Royal Microscopical Society, May 2,-H.C. Sorby, F.R.S., president, in the chair. A number of donations to the society were announced, including a sum of 5002 . presented by Mr. C. Lambert, from a bequest of $25,000 l$. left by that gentleman's late father, to be appropriated to benevolent and scientific purposes. 